\section{Watson suspended over comments on race}

James Watson, the geneticist credited with the co-discovery of the structure of DNA, has abandoned a book tour in Britain after suggesting that he thinks black people may be less intelligent than whites.

In an interview with the London-based Sunday Times, published on 14 October, the 79-year-old said he was "inherently gloomy about the prospect of Africa” because "all our social policies are based on the fact that their intelligence is the same as ours - whereas all the testing says not really".

After the comments were picked up by other media on 17 October, Cold Spring Harbor Laboratory in Long Island, New York, announced that it was suspending Watson from 'administrative duties' as chancellor of the Watson School of Biological Sciences there.

Watson said he regretted his comments, but criticism from senior US colleagues was unsparing. "He has failed us in the worst possible way," said Henry Kelly, president of the Federation of American Scientists. "It is a sad and revolting way to end a remarkable career."

See Editorial, page 948.

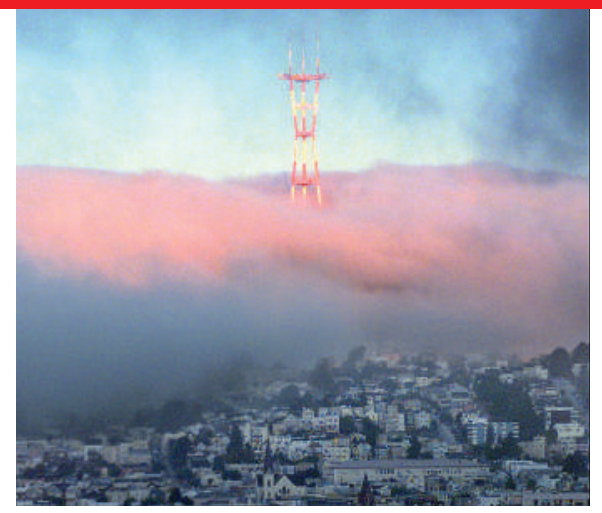

Sutro Tower in San Francisco hosts the first of

California's regional greenhouse-gas detectors.

\section{Greenhouse-gas sensors} tower over California

California has begun installing regional greenhouse-gas detection systems in metropolitan areas, becoming the first US state to gather such regional data.

Sensors have been placed on Sutro Tower in San Francisco and Richland Tower in the Sacramento suburbs as part of the California Greenhouse Gas Emissions Project, a collaboration between state and federal agencies and universities. They measure greenhouse-gas concentrations twice a day.

The project - started by researchers at the Lawrence Berkeley National Laboratory in Berkeley, California - plans eventually to monitor gases at ten locations, using the data to help establish whether California is reaching its goal of reducing atmospheric greenhouse gases by cutting state emissions. At present these total about 550 million tonnes a year.

\section{Senate retreats from bid to ease stem-cell restrictions}

US senators have pulled back from an effort to open up the rules restricting embryonic stem-cell research in the United States. On 17 October they dropped a clause that would have done so from the 2008 funding bill for the National Institutes of Health.

Senator Tom Harkin (Democrat, Iowa) says that the measure, which would have expanded the stem-cell lines available for federal funding, was dropped in a "spirit of compromise". Earlier that day, the White House had issued a policy statement declaring the provision "a transparent attempt to reverse the clear policy the President has implemented on the ethical conduct of stem cell research" and saying that Bush would veto any bill including it.

Bush's policy restricts federal funding to research on stem-cells lines developed before August, 2001; the withdrawn rider would have allowed US funding for work on scores 